\title{
The Guided-Inquiry-Worksheet Stimulating Process Skills and Concept Understanding in Indonesia Junior High School
}

\author{
Eni Fariyatul Fahyuni ${ }^{1^{*}}$, Rusijono ${ }^{2}$ and Siti Masitoh ${ }^{2}$ \\ ${ }^{1}$ Faculty of Islamic Studies, Universitas Muhammadiyah Sidoarjo, Jawa Timur, Indonesia. \\ ${ }^{2}$ Faculty of Educational Technology, State University of Surabaya, Jawa Timur, Indonesia.
}

\begin{abstract}
Authors' contributions
This work was carried out in collaboration between all authors. Author EFF designed the study, performed the statistical analysis, wrote the protocol and wrote the first draft of the manuscript. Authors Rusijono and SM managed the analyses of the study and managed the literature searches.

All authors read and approved the final manuscript.

Article Information

DOI: $10.9734 / A J E S S / 2019 / 44645$

Editor(s):

(1) Dr. E. Seda Koc, Faculty of Education Classroom Teaching, Hacettepe University, Turkey.

Reviewers:

(1) Idogho, Joseph Agofure, Federal University Oye - Ekiti, Nigeria.

(2) Nur Miftahul Fuad, Universitas Negeri Malang, Indonesia. Complete Peer review History: http://www.sciencedomain.org/review-history/27422
\end{abstract}

Original Research Article

Received 01 September 2018

Accepted 05 November 2018

Published 26 November 2018

\begin{abstract}
This research is developing guided-inquiry worksheet by analysing validity, practicality, and effectiveness to improve process skills and understanding at seventh-grade junior high school. Developed worksheet expected to connect and reflect "educator" and "learner". Learning science by worksheet using integrates learning from actual hands-on activities and minds-on activities. The data collected by questionnaires and practical observation analysed with the t-test. The result of validity is 3.83 , and the practical observation means 3,87 showed of $0,000<0,005$ which was significantly from conventional ones. Teachers who want to improve the skills and concept must use guided inquiry worksheet developed in this research.
\end{abstract}

Keywords: Guided inquiry worksheet; process skills; concept understanding.

*Corresponding author: Email: eni.fariyatul@umsida.ac.id, eni.fahyuni@mhs.unesa.ac.id; 


\section{INTRODUCTION}

Science subjects at junior high school have an important for their students on phenomena that occur in their environment. 21 st century learners have both self-direction and ability for individual or teamwork collaborate. Technology insight for development and improvement of knowledge, skills, and social attitude of teachers and students. Learning activity at state junior high school 2 Porong for science subjects was less interesting by tedious and troublesome materials to understand. Students have misconception that experience temperature and heat when the water in a glass is heated to a temperature of $t 0 C$. Students assume if the water poured each contains half the glass content of $0.5 \mathrm{t} \mathrm{0C}$. The occurrence of misconceptions, student makes learning for prioritizing in teaching science that should contain problems to find, collect, analyze and conclude in order to build understanding of a series of learning experiences. Teaching and learning doesn't only contain transformation of knowledge in theories, principles, and law. Teachers pattern should emphasize an effort student discover potentials to find solutions for solving various problems occurring [1].

The teaching pattern and selection of students are very significant for the competence of students in school. Students' low achievement in Indonesia has not shown significant changes. We can prove this 2011 TIMSS results and the 2012 PISA Indonesian students' achievements ranked 63 of the 64 participating countries [2]. TIMSS results in 2015 were also still below the average of other participating countries with Singapore and Malaysia [3]. Thus, the declare student learning results problem that needed to be handled quickly and the way students learn, question of phenomena occuring, and find solutions. This learning climate line with paradigm of constructivism learning. Learning constructivist its way involves students in social and cultural learning [4] .

According to Piaget [5], the cognitive development of junior high school at concrete operational towards at operations formal level. Vygotsky [6] zone of scaffolding given further reduced experience student. The process of learning was carried out by students through searching, collecting data, and analyzing the solution of problems [7] for this reason, teachers provide students to active, investigate, collect, problems analyze to find solutions together. Science is systematically of knowledge, tentative, dynamic, empirical, demonstrable, process and product, and natural phenomena [8]. That process skills are an activity process of inquiry. Suggest inquiry methods in science learning: 1) intellectual potential by training development; 2) intrinsic motivation; 3) the opportunity for discovery process; 4) strengthen of student memory [9].

\subsection{Teaching Situation}

The role of an educator in school become to guided students in what are they learning [10]. This is an accordance with the context of curriculum which emphasizes the holistic ability of students and teachers. Teaching wasn't focused on how to teach but more oriented to how stimulate learning [11]. Effective teachers are interactive and provide students become selfdirected, independent, and critical thinkers [12]. That teachers learn actively students and indirectly two competencies simultaneously. First, with conduct an investigative students to scientists/researchers. Second, Students investigation will get understanding complex what they have learned [6].

The teaching situation by guided-inquiry method can give students the opportunity to find variety of knowledges and experiences [7]. The teachers' role will function as facilitator and guide students to learn [13]. Effective learning involve series scientific investigations at process skills and concepts understanding [14]. Learning can do anywhere, anytime, and with anyone. Learning classroom for real life [15]. Learning science just not products, but also a process with collecting, analyzing, concluding and even applying in social life [1].

\subsection{Learning System}

The essence of learning science is not to produce science historians, but instead on how students can make judgments on knowledge, scientific and conceptual understanding [16]. Students through integrate the process of inquiry [14]. Science learning emphasizes efforts students potential and problem-solving with the community. Integration with science and inquiry have the opportunity to develop conceptual, procedural and problem-solving knowledge [1]. Vygotsky's cognitive development can develop maximally social interaction with expanded exploration and stimulation of students' curiosity [17]. That learning curiosity as the most important [18]. 


\section{MATERIALS AND METHODS}

\subsection{Research and Development}

Research and development are carried out to produce new products which are later tested for validity, practicality and effectiveness. The development model used refers to the system approach model by Dick and Carey [19] which consists of 10 stages.

\subsubsection{Assess needs to identity instructional goals}

Identification of needs and instructional goals are the basis for determining problems and constraints faced by students. Identification of learning is to identify gaps current conditions and expected conditions, as well as to assess whether the discrepancy is a priority to overcome because it greatly influences the overall competency of students. Identification performance carried out showing students in learning activities. In practicum activities, there is very few students' creativity built for problemsolving. Students don't make exploration scientific in practicum instructions. Ideally, science learning is emphasised on the activities of students finding out understanding of investigation. For this reason, teachers need to provide flexibility for students to actively move, investigate, collect data, test and analyse problems to find solutions together. Learning difficulties students related to prerequisite knowledge that students given new material they will learn and the ability: 1) material regarding principal and derivative quantities, 2) students understand the measurement of principal and derivative quantities. Therefore, science learning is not a product with students able to memorise facts, theories, principles and laws, but the most important is the process with students getting direct experience in learning. Instructional goals seventh grade sat Porong 2 Junior High School can be formulated by "growing with scientists for asking questions, investigating, analysing, building meaning through their learning experiences.

\subsubsection{Conduct instructional analysis}

After doing the identification process of learning objectives, the next step is the analysis of learning, which is a process to determine the skills, knowledge, and relevant attitudes needed by students to be able to achieve competencies for the stated learning goals of science. Conduct instructional analysis is the stage of describing learning objectives into sub-indicators into specific competencies refers to 1) describe competencies standards, 2) learning with taxonomy Bloom, 3) dimensions of learning, 4) technology and learning media [20]. Analysis of learning involves in teaching, namely, "what will be taught?" And "how to teach?" Teachers in school often choose and determine the material not based on needs, but rather on the order of delivery of learning material. Learning is a process of interaction between students and educators and learning resources in a learning environment.

\subsubsection{Analyse learner and context}

Analysis of students and the learning context is carried out simultaneously. Analysis of students' characteristics includes knowledge learned by students previously, academic abilities, learning styles, and learning activities. Identification of the characteristics of these students can help deviser to develop learning approaches and strategies that are in line with the expected learning objectives. Identification student characteristics can be done based on: 1) gender, 2) academic ability, 3) learning style, and 4) education and social, economic parental [19]. Analysis context at seventh grade junior high school 2 Porong related to the learning material that will be provided certainly considers: 1) the reality of school conditions, regarding the availability of facilities and infrastructure, as well as the school's vision and mission; 2) availability of learning resources; 3 ) time or timing of learning.

\subsubsection{Write performance objective}

Based on the learning, students, and context analysis when the teaching is carried out, a developer can translate them into subcomponents or specific learning objective components that can be mastered by students, which also refers to the general learning objectives set at the beginning. Specific learning objectives are the only basis in test contents based on its suitability to achieve the competencies listed in the stated goals.

\subsubsection{Develop assessment instrument}

After the specific learning objectives have been explained, the next step is to develop an assessment instrument as a result of the assessment of student learning outcomes 
following the specific learning objectives that have been set. The scores obtained by students in the learning outcome assessment interpreted as the level of mastery of the competencies they measure, which is comparing the maximum score students can achieve according to the learning objectives.

\subsubsection{Develop instructional strategy}

Developing and determining learning strategies is certainly related to the achievement of the learning objectives that have been formulated on the following factors: a) suitability with the theoretical basis, b) previous research results, c) characteristics of learning media used, d) material given to students, e) student characteristics and learning context. As for the development of learning strategies with guided inquiry methods, including 1) teacher prepares material in line with the expected learning objectives and estimates previous student; 2) learning activities carried with guided inquiry methods, namely: a) see (observe / focus inquiry processes on phenomena that occurs) b) ask (formulate questions or problems to students), c) prediction (make a temporary / hypothetical guess), d) investigate with guidance (plan and conduct an investigation), e) create (analyze data and interpret the results), and f) discuss \& communicate (conclude and communicate the results of the investigation; 3 ) in the final stage an evaluation and reflection of the teacher to improve the process of the next learning.

\subsubsection{Develop and select instructional materials}

Developing and choosing materials in learning is related to the use of learning media such as literature books that can help provide various information, and learning resources used are student textbooks, worksheets and so on. Develop and select instructional materials with collect materials available to learning strategies of teaching materials, for example in the form of powerpoints or apply with tools and materials provided properly and correctly to minimise the risk of work negligence for students. The following is one example of a teacher in developing conditional learning materials to adapt materials available and easily obtained by students at seventh-grade state junior high school 2 Porong. For this reason, the teacher must maximise learning resources by utilising used materials that are not used in the environment. Thus, it will be able to train and maximise the process skills and understanding of students' concepts even better.

\subsubsection{Design and conduct formative evaluation of instruction}

Designing and carrying out formative evaluations aims to determine the validity, practicality and effectiveness of the products developed seventh grade at state junior high school 2 Porong. The results of this formative evaluation later used as valuable suggestions and inputs for developers to revise the products produced. Three types of formative evaluation are carried out, which are: a) one to one evaluation consists of 5 learners, b) small group evaluation consists of 15 learners, and c) field trial consists of 34 learners.

\subsubsection{Revisi instruction}

At this stage, the data that came from suggestions and inputs from the expert team and users are assessed and interpreted for what its weaknesses that need to be revised immediately. The evaluation is not only done on the guided inquiry worksheet draft, but also on the various components involved during learning activities, such as analysis of students' initial abilities, student characteristics and school's context analysis. Formative evaluation was carried out on all learning components with the aim of fixing and improving the quality of the developed guided inquiry worksheet. The revisi instruction is an important component for teachers and developers product to according to of expert validation, individual trials, group trials and field trials in the learning process through revision product will be perfected and accordance with their needs.

\subsubsection{Design and conduct summative evaluation of instruction}

The summative evaluation could be done after formative evaluation and complete revision. Summative evaluation shouldn't be carried out and involve develop internally, but rather make a separate independent assessment team. This is one of the reasons that states summative evaluation does not belong to the Dick and Carey learning system design process.

\subsection{Instruments Collection}

This data instrument on research and development was conducted to determine 
validity, practicality and effectiveness of guided inquiry worksheets to improve process skills and conceptual understanding. The subjects of this study were seventh, according to Piaget in [5] the cognitive development in the state transition of concrete operations towards formal operations, at this stage students needed more help or scaffolding than the others [17]. Class at seventh were 145 students who were selected based on student age, academic ability, type of elimination, and educational background and economic conditions of parents who had no significant differences that could lead to invalid assessment.

\subsubsection{Validity instrument}

The developed instrument was a guided inquiry worksheet validation sheet made by a team of experts. Validity aspects that are assessed including; specificity, accuracy, uniformity and suitability [21]. the validity aspect consists of linearity, uniformity, accuracy, specificity, reliability, and accuracy [22]. The validity aspects include usefulness, integration, balance, learning interaction, form, colour, and language. Thus the aspect of validity assessed by the team of experts includes: a) specific, b) accuracy, c) integration, d) usefulness, e) reliability, and f) learning interaction [23].

\subsubsection{Practicality instrument}

The developed practical instruments were guided inquiry worksheets observation sheets which including a) content quality, b) learning techniques quality, and c) learning messages delivering quality. The components contained in the guided inquiry worksheet consisted of: the problems presented are clarified with the help of drawings/ charts/graphs, tools and materials used, work safety guidelines during practicum, students conclusion and report of the results of the investigation. The learning syntax of using guided inquiry method was: 1) see (students observe the physical phenomena that occur), 2) ask (the teacher raises the problem), 3) prediction (students create hypotheses), 4) investigate (students conduct a series of investigations), 5) create (students analyze data and interpretation of results), and 6) discuss \& communicate (conclude and communicate the results of investigation).

\subsubsection{Effectiveness instrument}

The effectiveness instrument is developed by making multiple choice and essay questions that were given to students at pre-test and post-test to determine differences in results between after and before being given teaching between students using guided inquiry worksheets and students using conventional worksheets. Ikhsan, That effectiveness can be assessed by comparing the pre-test and post-test scores of students' learning results towards the achievement of predetermined learning goals.

\section{RESULTS AND DISCUSSION}

\subsection{Validity Analysis}

The result of feasibility validation of the guided inquiry worksheet in materials of temperature and heat showed that Graphic 3.1 validity analysis at the four sub-materials have an average score of 3.77 , which means that they are very valid to be used in science tools learning in schools. Guided inquiry worksheets must be accompanied by work safety instructions to prevent students from occurring errors that are fatal during the investigation.

The novelty of the guided inquiry sheet of this worksheet was adapted according to the school context by giving students the freedom to actively move, investigate, collect, test, analyze and determine the solution together so students could gain skills, opportunities to do practical activities, provide feedback, and remedies for those who have not mastered the certain material [24].

\subsection{Practicality Analysis}

To analyse practicality of learning with guided inquiry worksheet were observations practicum student. Temperature and heat material divided into four topics, including 1) temperature and thermometer, 2) expansion, 3) heat and 4) heat transfer. The observations of each subsequent learning will be averaged to conclude the results of practicality.

The results of the observation of the guided inquiry worksheets Graphic 3.2 practicality analysis usage content material/quality, learning techniques, and messages delivering found an average score of 3.57 in the very good category. Leaning techniques and messages delivering some items: 1) make a conclusion and reflection with a score of 3.13 or $78 \%$, and 2) work safety with a score of 3.35 or $81 \%$. Thus, the use of guided inquiry worksheets need to be 
maximised the part of students in making conclusions and reflections and paying attention to work safety procedures during the investigation process.

This is supported by research that learning by inquiry method effectively helps students build basic concepts understanding in learning [25]. Implementing inquiry learning, students have conceptual understanding and enable to integrate different aspects into a coherent entity so that they can broaden their understanding by using integrated and complex reasoning and planning [26]. Questionnaire research consist: 1) student involvement, 2) learning enthusiasm, 3) material suitability, 4) problems solving, 5) flexibility learning, and 6) use of the environment as a learning resource.

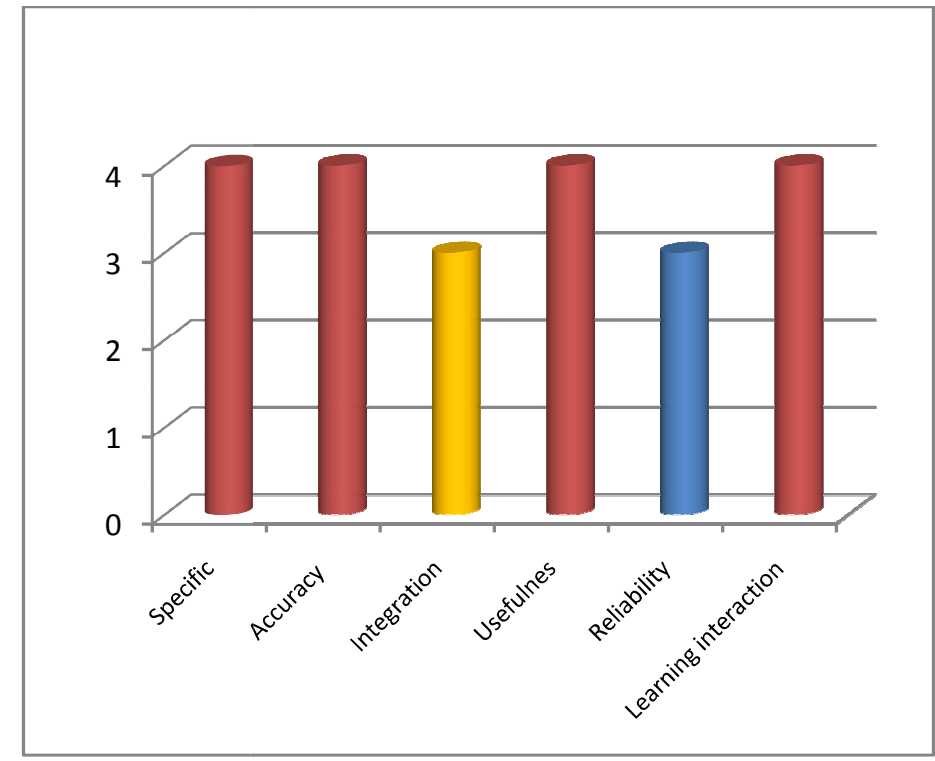

Graphic 3.1. Validity analysis

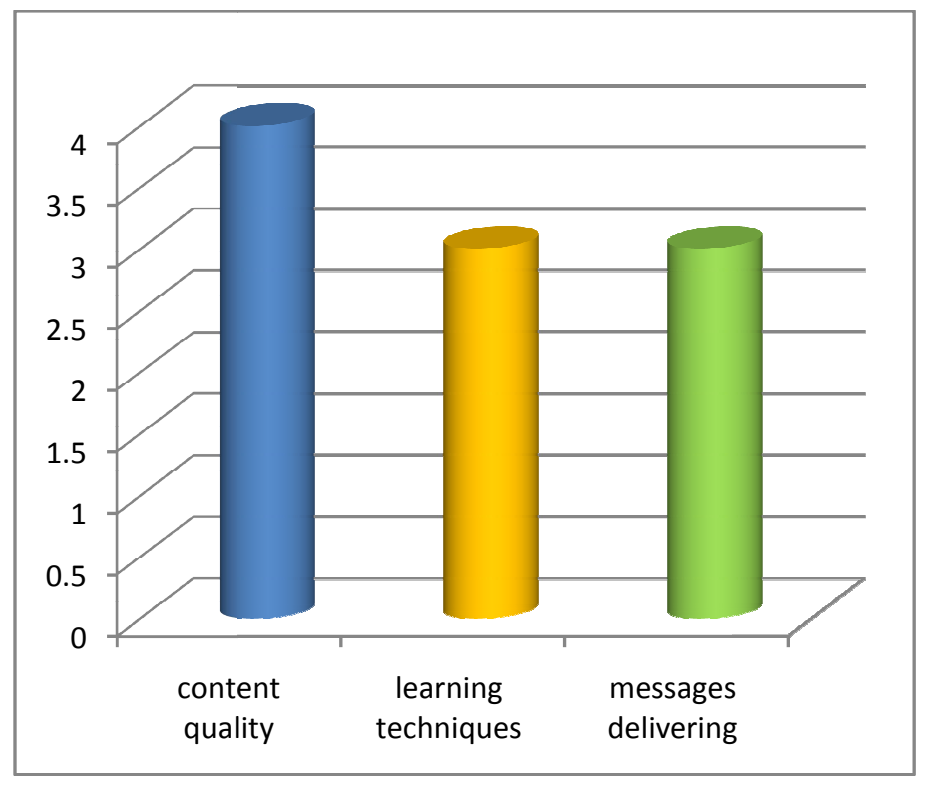

Graphic 3.2. Practicality analysis 


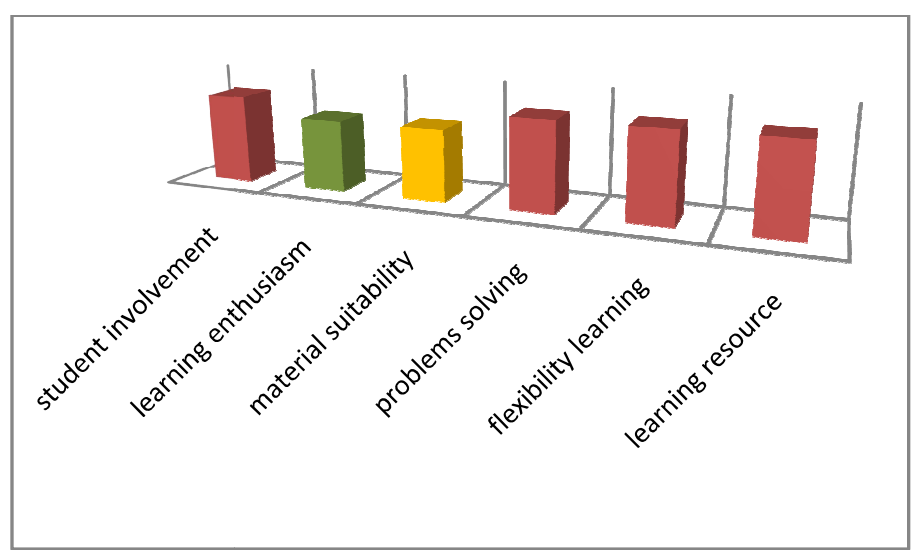

Graphic 3.3. Results of questionnaire

The graph questionary explains that learning with guided inquiry methods includes: 1) student learning involvement is increasing. The guidedinquiry method providetos flexibility. 2) problem solving faced with various problems to find a solution, 3) learning is flexible, tools and materials suit at students characteristic and the school context, 4) learning resources available at the school. 5) learning interest, related teacher presenting learning material and 6) suitability of learning material, innovative teacher, motivating, encouraging to increase the spirit of learning.

\subsection{Effectiveness Analysis}

\subsubsection{Observation results for practicum}

Observation practicum find out for process skills in the practicum process, including 1) observing and collecting data; 2) grouping; 3) comparing; 4) preparing results in the form of scale/graph / picture; 5) paying attention to work safety; 6) concluding the results of the trial; and 7) compiling reports.

The results of the practical activities at two groups were processed by SPSS version 16 by using a two-sample independent T-Test which showed a Sig (2-tailed) value of $0.000<0.05$. This means there are significant differences process skills in group $A$ using guided inquiry worksheets and group B using conventional worksheets.

Observations class practicum on group B conventional worksheets all aspects of assessment in the low category. Some items that need to get the teacher's attention: 1) aspects conclusions and reports, and 2) paying attention to be maximised students careful, procedures accordingly, and make scientific well of the investigation report on science subjects.

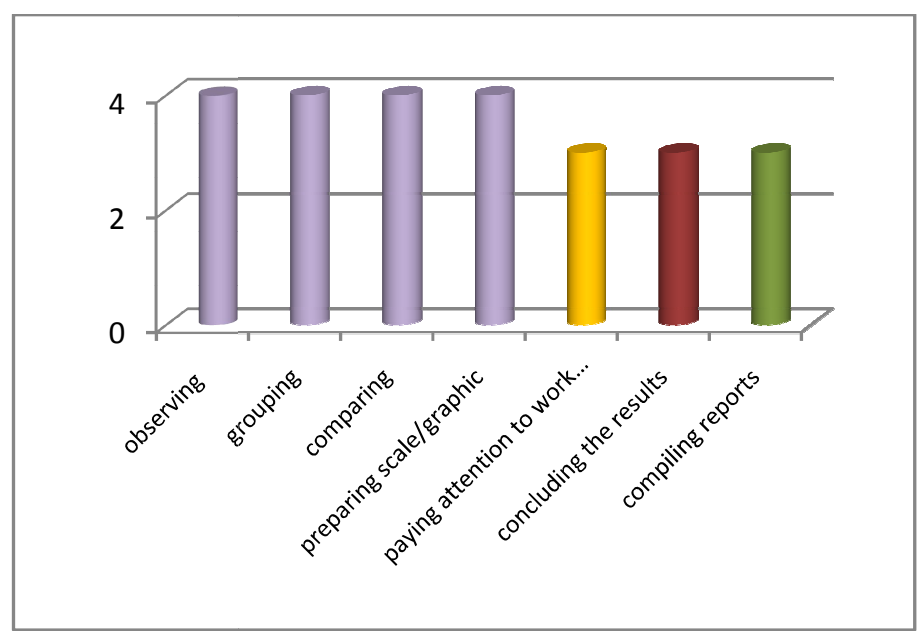

Graphic 3.4. Practicum learning analysis 
This concept of understanding means its reconstruction, not just the process of assimilation that has been previously owned. Concept understanding divided into three ways regarding breadth, depth, organisational structure [27]. That students able to interpret, remember, integrate, and reason about the concept [28]. This is following the results of [26] research that guided inquiry worksheets developed by inquiry method can mould young scientists in schools with students searching, collecting data, investigating, analysing to build their understanding of what they are learning actively.

\subsubsection{Learning test results}

Based on the results of data processing using SPSS 16 program, the learning test results showed the level of difficulty in multiple choice questions, which had 11 questions with easy criteria, 20 questions with medium ones, and 9 questions with difficult ones. The different power index questions showed there are 20 questions with good criteria, 6 questions with medium ones and 4 questions with bad ones. Normality test is used to assess the data distribution of both groups (experimental group and control group) indicating that the distribution of data is normally distributed.

The homogeneity test is used as a condition in analysing the T-test, which obtained the Sig (2tailed) value of 0.63 indicating the data variance of the two groups is homogeneous. Furthermore, the results of the pre-test of both groups showed the Sig (2-tailed) value was $0.434>0.05$, meaning that there were no differences in the initial abilities of the two groups. While the results of the post-test T-Test for both groups showed the Sig (2-tailed) value was $0.000<0.05$. This means that there are differences in learning outcomes of both groups. For this reason, teachers who want to improve their processing skills and conceptual understanding for their students are advised to use guided inquiry worksheets which are proven to be very helpful for students in obtaining better process skills and conceptual understanding that students who use conventional worksheets.

\section{CONCLUSION}

The novelty of developed guided inquiry worksheets emphasize situations where students find out what is happening, manipulate objects/symbols, ask questions and try to find their answers, match what they find in a time with what they found at another time, and compare their findings with the findings of other students, all by themselves. Science process skills acquired in science learning can facilitate and encourage students to discover their concepts of knowledge, facts and develop attitudes and moral values in their daily lives.

Junior High School at 2 Porong is one of the junior high schools in Sidoarjo district, that researchers as a basic level education institution lots of advice and direction for teachers/researchers. Porong 2 Junior High School Institution stated the truth of the data and had conducted a practicum test. The developed guided inquiry worksheet has conformity with the learning characteristics of school science that is maximising aspects of scientific attitudes, scientific processes, and scientific products with students actively carrying out a series of investigations meaningful understanding and to be able to feel the benefits of answering various problems in their lives. For the sustainability of guided inquiry worksheet, teacher integrates with others. Indonesian language study makes scientific writing and systematic. Study with utilising tools and materials from the surrounding environment to make a simple thermometer of liquid which has usefulness as well as a thermometer. This guided inquiry worksheet is recommended to be applied and improve process skills and understanding concepts at junior high school 2 Porong.

\section{ETHICAL APPROVAL}

This research and development were carried out at Porong 2 Junior High School for 4 months, where the research permit from the research study site, Surabaya State University, issued a letter requesting permission to study at the school. The principal as the highest leader has agreed. This is evidenced by the school's willingness letter for researchers to conduct research in class VII.

\section{ACKNOWLEDGEMENTS}

The researcher appreciation student for seventh grade at state junior high school 2 Porong (SMPN 2 Porong), headmaster, teachers and Ministry of Research, Technology and Higher Education of the Republic Indonesia who was very supportive for the accomplishment of this study result, as well as other partaker involved in this research. 


\section{COMPETING INTERESTS}

Authors have declared that no competing interests exist.

\section{REFERENCES}

1. Eggen, Kauchak. Methodes for teaching: Promoting student learning in $\mathrm{K}-12$ classrooms. Publishing as Allyn: New Jersey-USA; 2009.

2. OECD \& PISA results: Ready to learnstudents engagement, drive and selfbeliefs. Paris: PISA. OECD Publishing; 2013. Paris: PISA; 2012.

3. OECD \& PISA results: What students know and can do - students performed in mathematics, reading and science. OECD Publishing' 2014. Paris: PISA; 2012.

4. Arends, Richard I. Learning to teach $9^{\text {th }}$ edition. New York: McGrand Will Companies.Inc; 2011.

5. Santrock, John W. Educational psychology $5^{\text {rd }}$ ed. Boston: McGraw-Hill; 2015.

6. Slavin, Robert E. Psikologi pendidikan. Teori dan praktik. Jakarta: PT Indeks; 2011.

7. Kuhlthau C. Guided inquiry: School libraries in the 21st century. School Libraries Worldwide. 2010;16:17-28.

8. Ramesh M, Patel RC. Critical pedagogy for constructing knowledge and process skills in science. Journal Educationia Confab. 2013;1: 98-105.

9. Sund, Trowbridge. Teaching science by inquiry in the secondary school. Columbus: Charles E. Merill Publishing Company; 1973.

10. Loongworth $\mathrm{N}$. Making lifelong tearning work: learning cities for learning century. London: Kogan; 1999.

11. Hammer. Recognition of teaching excellence. American Journal of Pharmaceutical Education. 2010;74: 1-11.

12. Bodrova E, Leong DJ. Vygotskian and post-Vygotskian views on children's play. American Journal of Play. 2015;7(3):371388.

13. Karak EE, Yenice N. The investigation of scientific process skill level elementary education 8th grade studen in view of demographic featus. Procedia Social and Behavioral Sciences. 2002;46:3885-3889.

14. Balim AG. The effects of discovery learning on students success and inquiry leaning skills. Journal of Educational Research. 2009;35(1):1-20.

15. Dewey. Democracy and Education. Release date July 26 (ebook 852) Produced by David Reed and David Widger; 2007.

16. Leonor, Jigger. Exploration of conceptual understanding and science process skills: $A$ basis for different science inquiry curriculum. International Journal of Information and Education Technology. 2015;5(4):215-232.

17. Vygotsky LS. Mind and society: The development of higher psychological processes. Cambride:MA Harvard University Press; 1978.

18. Friedman TL. The World is flat: A brief history of the 21st century. New York: Farrar Straus Giroux; 2007.

19. Dick W, dan Carey L. The Systematic Design of Instruction. Fifth Edition. New Jersey: Pearson Education Inc; 2009.

20. Shambaugh N, Magliaro S. Instructional design (a systematic approach for reflective approach). United States of America: Pearson Education Inc; 2006.

21. Sandoval, et al. Development and validation of abioassay to evaluate binding of adalimumab to cell membrane-anchored TNF using flow cytometry detection. Journal of Pharmaceutical and Biomedical Analysis. 2018;15(5):235-24.

22. Ramaswamy, Dhas. Development and validation of analytical method for quantitation of Emtricitabine, Tenofovir, Efavirenz based on HPLC. Arabian Journal of Chemistry. 2018;1(1): 275-281

23. Shuel TJ. Phase of meaningful learning. Review of Educational Research. 1990;1(6): 531-541.

24. Fransisca. Pengujian validitas, praktikalitas, dan efektivitas media elearning di sekolah menengah kejuruan. Jurnal Pendidikan Teknik Elektro. 2016;2(1):17-22.

25. Abdi A. The effect of inquiry based learning method on students' academic achievement in science course. Universal Journal of Educational Research. 2014;2(1):37-41.

26. Fahyuni, Eni F. Rusijono and Masitoh. The Guided inquiry worksheet: growing with scientist in Indonesia middle school. Advances in Social Science, Education and Humanities Research (ASSEHR). 2018;125:113-115. 
27. Entwistle N, dan Entwistle A. Revision and the experience of understanding. The experience of learning: implications for teaching and studying in higher education (3rd internet edition). Edinburgh: University of Edinburgh, Centre for Teaching, Learning and Assessment. 2007; 145-155.

28. Gott R, dan Duggan S. Investigative work in the science curriculum. Bungkingham: Open University Press; 1995.

(c) 2019 Fahyuni et al.; This is an Open Access article distributed under the terms of the Creative Commons Attribution License (http://creativecommons.org/licenses/by/4.0), which permits unrestricted use, distribution, and reproduction in any medium, provided the original work is properly cited.

Peer-review history:

The peer review history for this paper can be accessed here: http://www.sciencedomain.org/review-history/27422 